I N S T I T U T O

DE

M E D I C I N A

T R O P I C A L

DE

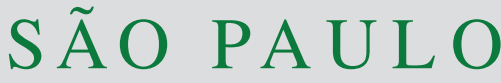

JOURNAL OF THE SÃO PAULO INSTITUTE OF TROPICAL MEDICINE

${ }^{1}$ Instituto Evandro Chagas, Programa de Virologia, Ananindeua, Pará, Brazil

Universidade Federal do Pará, Programa de Biologia e Agente Infeciosos e

Parasitários, Ananindeua, Pará, Brazil

${ }^{3}$ Instituto Evandro Chagas, Programa de Iniciação Científica, Ananindeua, Pará, Brazil

${ }^{4}$ Universidade do Estado do Pará,

Faculdade de Medicina, Belém, Pará, Brazil.

${ }^{5}$ Instituto Evandro Chagas, Ananindeua, Pará, Brazil

Correspondence to: Caio Vinicius Botelho Brito

Instituto Evandro Chagas, Programa de Virologia, Rodovia BR-316, $\mathrm{Km} \mathrm{7,} \mathrm{s/n,}$ Levilândia, Ananindeu, PA, Brazil

Tel: +55 91 3214-2233

E-mail: caiovbb@yahoo.com.br

Received: 10 January 2021

Accepted: 15 March 2021

\section{Immunological impact of tetrahydrobiopterin on the central nervous system in a murine model of rabies virus infection}

\author{
Caio Vinicius Botelho Brito ${ }^{(1)}$, Érika Dayane Leal Rodrigues ${ }^{(2)}$, Fernanda \\ Monik Silva Martins ${ }^{(1)} 3$, Lavinia Dias Tavares ${ }^{(1)} 3$, André Luis de Sousa \\ Nogueira Lima ${ }^{\circledR 3}$, Lucas Carvalho Ferreira ${ }^{\circledR 3}$, Carlos Junior Lopes \\ Santana ${ }^{(1)}{ }^{3}$, João Augusto Gomes de Souza Monteiro de Brito ${ }^{\circledR} 4$, Lívia \\ Medeiros Neves Casseb ${ }^{(15}$, José Antonio Picanço Diniz Junior ${ }^{(1)} 5$
}

\section{ABSTRACT}

Currently, the Milwaukee protocol presents healing results in human beings affected by the rabies virus. However, there are many points to clarify on the action of drugs and the immune mechanism involved in the evolution of the disease. One of the drugs used is biopterin, which is an important cofactor for nitric oxide, important for preventing vasospasm. Thus, we describe the effect of biopterin on some inflammatory factors in a rabies virus infection developed in an animal model. The immunological mediators studied in animals infected with rabies virus submitted to doses of sapropterin were Anti-RABV, IL-6, IL-2, IL-17a, INF-gamma and Anti-iNOS. It is suggested that the medication in the context of a RABV infection already installed, had the effect of modulating the inflammatory mechanisms mainly linked to the permeability of the blood-brain barrier and the migration of cytotoxic cells.

KEYWORD: Rabies. Rabies virus. Tetrahydrobiopterin. Blood-Brain Barrier. Interleukin-6.

\section{INTRODUCTION}

The Rabies virus (Rabies Lyssavirus - RABV) is an RNA virus of the family Rhabdoviridae that presents tropism for the nervous system, causing encephalitis ${ }^{1,2}$. The onset of the symptoms occurs from one to three months after exposure to saliva or fluids of an infected mammal, which may occur after a longperiod ${ }^{2}$. The disease has three classic forms: the furious form, the paralytic form and the atypical form. The outcome of human rabies cases is, in most cases, death and the time for it to occur varies according to the support given to the patient ${ }^{3,4}$.

The surviving rate of patients with encephalitis is low. Survivors were submitted to the Milwaukee protocol, which aims are to reach an early stabilization of the patient and control of dysautonomies resulting from neuronal and inflammatory dysfunctions generated by the virus ${ }^{5-7}$.

One of the pharmacological components of the protocol is tetrahydrobiopterin (BH4), with its functional pharmacological form, sapropterin, a cofactor in the synthesis of nitric oxide, also participating in the metabolism of phenylalanine into tyrosine and in the conversion of tyrosine to levodopa and tryptophan to 5-hydroxytryptophan. Clinically, it is indicated for phenylketonuria, which is caused by a metabolism error in the production of $\mathrm{BH} 4$ due to a failure of the enzyme dihydropteridin reductase, affecting the central nervous system metabolism in several ways ${ }^{8,9}$.

BH4 is used specifically in rabies virus infection due to its reduced dosages 
in the cerebrospinal fluid (CSF) of infected patients and the fact that it can, in theory, prevent cerebral spasms by regulating the production of nitric oxide. In the protocol, there is an association of $\mathrm{BH} 4$ with ascorbic acid to promote the recycling of dihydrobiopterin into tetrahydrobiopterin, administered together to control the disease, concomitantly with amantadine, fludrocortisone, nimodipine and ketamine, each of them with precise indications, but they are not within the scope of this study ${ }^{8,9}$. Thus, the aim of the present study is to analyze the immunological effect of biopterin on rabies virus infection, in a murine model.

\section{MATERIALS AND METHODS}

\section{Viruses and drugs}

In this study, samples of the wild strain rabies virus from bats carrying the antigenic variant (VAg 3) were used, provided by the Section for Arboviruses and Hemorrhagic Fevers (SAARB) of the Evandro Chagas Institute (IEC), Para State, Brazil more specifically from the Rabies Laboratory. The sample was titrated to 3.2 DL $50 / 0.02 \mathrm{~mL}$ using the Reed and Muench method ${ }^{10}$.

The drug used was tetrahydrobiopterin (Sapropterin form) $(50 \mathrm{mg} / \mathrm{kg} / \text { day })^{11}$ orally administered by gavage, which consists of the introduction of an aluminum cannula device for mice that allows the intra-gastric inoculation of the medication. The commercial name of the drug is KUVAN $^{\circledR} 100 \mathrm{mg}$, soluble tablets with sapropterin and dihydrochloride as an active ingredient.

\section{Infection experiment}

Thirty-seven female BALB-C mice (M. musculos) aged 3-4 weeks, with a maximum of 5 animals in each cage $(50 \times 60 \mathrm{~cm})$, were used. The animals received water and feed at will, and with respect to the circadian cycle, they were placed in appropriate structures for cages to maintain the air circulation. The experimental model of rabies inoculated a suspension containing $20 \%$ of the brain of a mouse with the antigenic variant $3(\mathrm{VAg} 3)$ of RABV, in a titration of 3.2 DL50 $0.02 \mathrm{~mL}$, leading to a $0.03 \mathrm{~mL}$ intramuscular (IM) injection in the lateral region of the right hind leg.

The animals were euthanized with Xylazine and Ketamine in double doses, followed by cardiac puncture, so that a better analysis could occur by the proposed methods.

\section{Treatment with biopterin}

The 37 infected animals were divided into two groups: the control group (19 animals), with only infection, and the tetrahydrobiopterin group (18 animals), in which sapropterin was administered via gavage. The animals were followed for 17 days of disease progression and on the first day of manifested symptoms, the administration of the drug to all animals began. Then, the groups were paired, following the experimental case-control design of the study. The choice to start the treatment after the onset of symptoms in the first animal intended to mimic the disease in humans, and after the disease establishment, this animal was subjected to a direct immunofluorescence test to confirm the presence of the infection.

Every day gavages were carried out with the drug calculated for each animal weight, diluted in $0.9 \%$ saline. On days: 3, 5, 7, 9, 11 and 13 of drug administration, three animals from each group were euthanized to analyze the effect of the medication on the markers proposed in this study.

The following immunological markers anti-RABV, IL-6, interferon gamma, IL-2, IL-17a and Anti-iNOS were analyzed on three animals/ day over the course of 13 days, and the cerebral hemisphere was collected for analysis and comparison purposes.

\section{Flow cytometry}

After maceration, the hemi-brains of all mice were analyzed, the technique was performed according to the manufacturer's instructions (BDTM Cytometric Bead Array (CBA) Mouse Inflamatory- BD Biosciences/USA) in order to analyze the production of cytokines interleukin -2 (IL-2), IL-6, interferon-gamma (IFN-gamma) and IL-17A. The samples were evaluated on the flow cytometer (BD FACSCanto II), the data were processed by the FACS DIVA software and statistical analysis on the GraphPad Prism 5 software (5.0, GraphPad Software, San Diego, EUA) using the One-way ANOVA test with $\mathrm{p}<0.05$.

\section{Immunohistochemistry}

In the immunohistochemical processing, the immunoperoxidase technique was used for immunostaining with a commercial Vector Mouse on Mouse Basic Kit (M.O.M. kit, Vector Laboratories, Burlingame, USA) in compliance with the manufacturer's instructions withmodifications. Slides containing histological sections of the organs were deparaffinized in increasing concentrations of xylol (50\% and 100\%) and decreasing concentrations of alcohol $(100 \%, 95 \%, 80 \% 70 \%$ and $30 \%)$ and later washed with distilled water.

For antigenic recovery, tissue cuts were incubated at a high temperature in a pressure cooker for $30 \mathrm{~min} / 125^{\circ} \mathrm{C}$ 
with tris-citrate $\mathrm{pH}: 7.2$, subsequently permeabilized with $0.5 \%$ Triton X 100 solution, followed by the blocking of nonspecific sites with a solution containing Mouse $\operatorname{IgG}$ Blocking Reagent incubated as the primary antibody for $1 \mathrm{~h}$, followed by washing in PBS to continue the incubation in a protein concentrate solution for $30 \mathrm{~min}$.

The incubation with the primary antibody occurred for $12 \mathrm{~h}$ under agitation followed by washing; for the next incubation in hydrogen peroxide diluted in water (proportion of 1:10) for $15 \mathrm{~min}$ and finally tissue cuts were incubated in the $\mathrm{ABC}$ reagent for 1 hour.

For the immunohistochemical reactions, the DAB/nickel solution was used, mounted between slide/coverslip with Entellan (Merk, Germany), analyzed in a light field optical microscope (Axiophot - Zeiss, Oberkochen, Germany) and photographed with a digital camera (AxioCam HRC-Zeiss, Oberkochen, Germany).

The reagents used to analyze the brains of euthanized animals were Anti-RABV and Anti-iNos (Figure 1). The counting of marked cells was made with a grid in ten 400x magnification fields.

\section{Statistical analyses}

The Student independent $\mathrm{t}$ test was used to compare the tetrahydrobiopterin group and the control group and the ANOVA one criterion was used within each group, and between the results obtained on days 3, 5, 7, 9, 11 and 13, and a $\mathrm{p}$ value $<0.05$ was considered significant. Data were tested to confirm that a normal distribution has taken place.

In the evolution line of the tables, the values of increase or decrease in the time line were calculated, the plus sign $(+)$ being the increase and the minus (-) sign, the decrease.

\section{RESULTS}

Table 1 shows the results of the anti-RABV analysis, with a higher mean of detectable antibodies visible in
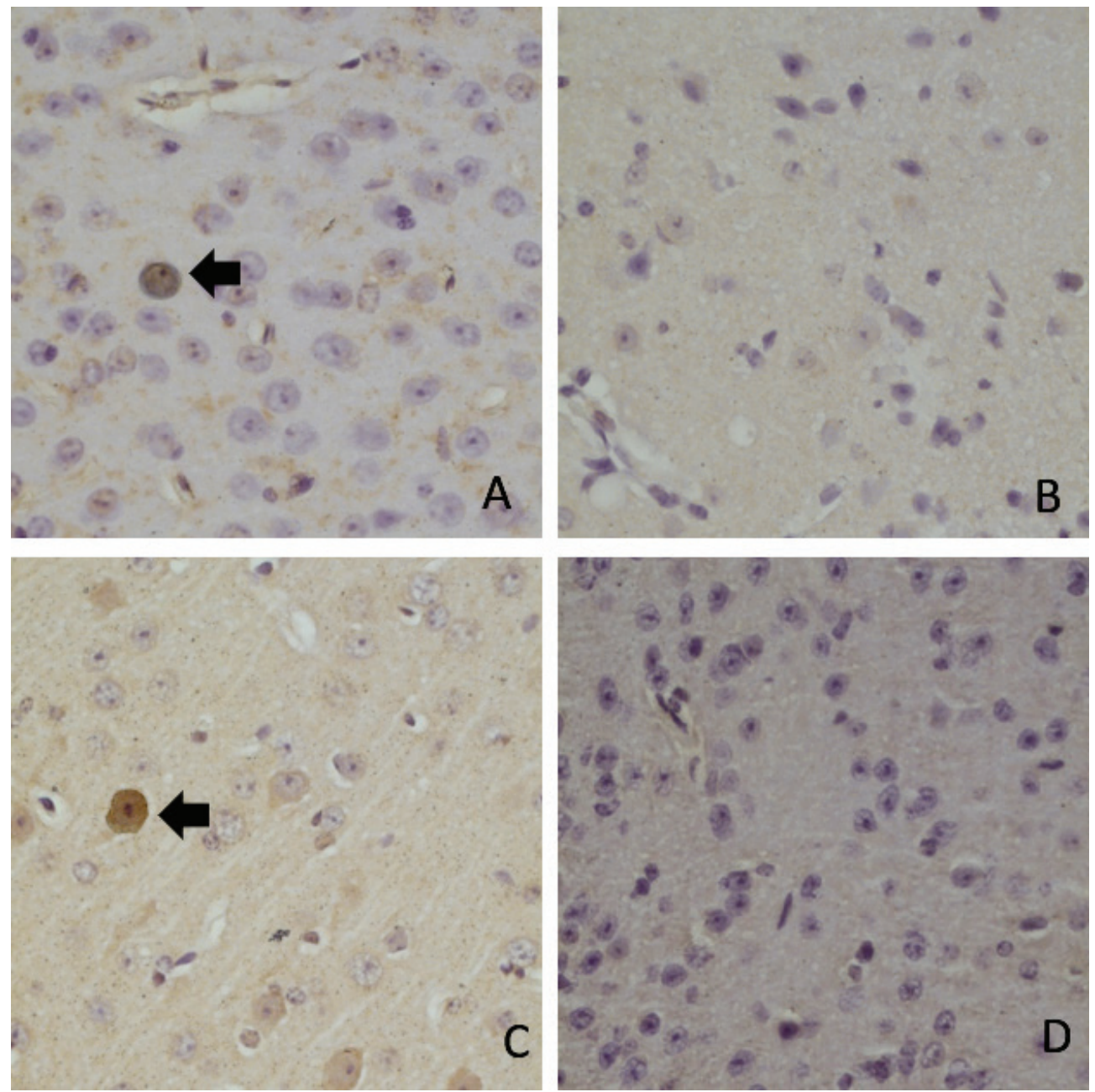

Figure 1 - Immunohistochemistry images of the nervous tissue of the studied mice: A) Nervous tissue marked with anti-i-NOS. The arrow points to a positively-marker cell; B) A negative control of anti-i-NOS in nervous tissue; C) Anti-RABV marking, with the arrow pointing to a positively- marked cell; D) A negative control of anti-RABV. 
the experimental group, being not possible to verify the oscillation in relation to time $(\mathrm{p}=0.045)$. However, it is worth noting that the group submitted to the drug had significantly lower values than the control group. In Table 2, there was a comparison of IL- 6 between the groups, with no statistical differences $(\mathrm{p}=0.2113)$. After the ninth day of medication, the animals in the group using sapropterin did not present detectable amounts of IL-6.

Table 1 - Comparison of anti-RABV immunohistochemistry analysis in the Infection Control and the Infection Experimental group, in mice, IEC, Brazil, 2020.

\begin{tabular}{cccc}
\hline \multicolumn{4}{c}{ Anti-RABV } \\
\hline $\begin{array}{c}\text { Time } \\
\text { (days) }\end{array}$ & $\begin{array}{c}\text { Tetrahydrobiopterin } \\
\text { group } \\
\text { Mean } \pm \text { SD }\end{array}$ & $\begin{array}{c}\text { Control group } \\
\text { Mean } \pm \text { SD }\end{array}$ & p-value \\
\hline 3 & $0.15750 \pm 0.049$ & $0.38292 \pm 0.086$ & $\mathbf{0 . 0 0 8 6 ^ { * }}$ \\
5 & $0.41000 \pm 0.103$ & $0.41000 \pm 0.103$ & ----- \\
7 & $0.39028 \pm 0.329$ & $0.34833 \pm 0.085$ & 0.4207 \\
9 & $0.29114 \pm 0.163$ & $0.34167 \pm 0.025$ & 0.3248 \\
11 & $0.28333 \pm 0.154$ & $0.35632 \pm 0.044$ & 0.2368 \\
13 & $0.32398 \pm 0.015$ & $0.15833 \pm 0.079$ & $\mathbf{0 . 0 1 1 5 ^ { * }}$ \\
\hline Result & +0.16648 & -0.22459 & \\
p-value & $\mathbf{0 . 0 4 5 3}^{\star *}$ & $\mathbf{0 . 0 1 9 2 ^ { * * }}$ & ------- \\
\hline
\end{tabular}

${ }^{\star}$ Student Independent t-test; ${ }^{\star \star}$ One-Way ANOVA test

Table 2 - Comparison of IL-6 Flow Cytometry analysis in the Infection Control and the Infection Experimental group in mice, IEC, Brazil, 2020.

\begin{tabular}{ccc}
\hline \multicolumn{2}{c}{ IL-6* } \\
\hline $\begin{array}{c}\text { Time } \\
\text { (days) }\end{array}$ & $\begin{array}{c}\text { Control group } \\
\text { Mean } \pm \text { SD }\end{array}$ & $\begin{array}{c}\text { Tetrahydrobiopterin } \\
\text { group } \\
\text { Mean } \pm \text { SD }\end{array}$ \\
\hline 3 & $3.1100 \pm 2.81$ & $4.1200 \pm 3.59$ \\
9 & $3.5450 \pm 5.01$ & 0.0000 \\
13 & $0.4967 \pm 0.86$ & 0.0000 \\
\hline Result $^{* *}$ & -2.6133 & -4.1200 \\
p-value & 0.5241 & 0.1338 \\
\hline
\end{tabular}

${ }^{*} p=0.2113$ Student Independence t-test; ${ }^{* *}$ One-Way ANOVA test

As for the inflammatory marker INF-gamma (Table 3), it was evaluated only in three days of the total of 13 days of the study, just like IL-6, for practicality in data analyses. A small fall in INF-gamma brain concentrations was observed in the group that received the drug studied $(\mathrm{p}=0.3856)$. The same occurred with IL-2 (Table 4), the experimental group had a small drop in this inflammatory mediator $(\mathrm{p}=0.0401)$. The opposite occurred with respect to IL17a (Table 5), that showest the greatest reduction in the infection in the experimental group $(\mathrm{p}=0.0146)$.
Table 3 - Comparison of IFN-gamma Flow Cytometry analysis in the Infection Control and the Infection Experimental group in mice, IEC, Brazil, 2020.

\begin{tabular}{ccc}
\hline \multicolumn{3}{c}{ IFN-gama* $^{*}$} \\
\hline $\begin{array}{c}\text { Time } \\
\text { (days) }\end{array}$ & $\begin{array}{c}\text { Control group } \\
\text { Mean } \pm \text { SD }\end{array}$ & $\begin{array}{c}\text { Tetrahydrobiopterin } \\
\text { group } \\
\text { Mean } \pm \text { SD }\end{array}$ \\
\hline 3 & $4.9100 \pm 1.01$ & $4.7500 \pm 1.17$ \\
9 & $4.5300 \pm 0.49$ & $3.7200 \pm 0.43$ \\
13 & $3.6267 \pm 0.07$ & $4.1450 \pm 0.05$ \\
\hline Result & -1.2833 & -0.6050 \\
p-value & 0.1529 & 0.3547 \\
\hline
\end{tabular}

${ }^{*} p=0.3856$ Student Independent t-test; ${ }^{* *}$ One-Way ANOVA test

Table 4 - Comparison of IL-2 Flow Cytometry analysis in the Infection Control and the Infection Experimental group in mice, IEC, Brazil, 2020.

\begin{tabular}{ccc}
\hline \multicolumn{2}{c}{ IL 2* } \\
\hline $\begin{array}{c}\text { Time } \\
\text { (days) }\end{array}$ & $\begin{array}{c}\text { Control group } \\
\text { Mean } \pm \text { SD }\end{array}$ & $\begin{array}{c}\text { Tetrahydrobiopterin } \\
\text { group } \\
\text { Mean } \pm \text { SD }\end{array}$ \\
\hline 3 & $11.6933 \pm 1.57$ & $9.9767 \pm 3.61$ \\
9 & $8.3150 \pm 2.92$ & $7.9867 \pm 0.56$ \\
13 & $5.4033 \pm 2.12$ & $9.7750 \pm 1.10$ \\
\hline Result & -6.2900 & -0.2017 \\
p-value & $\mathbf{0 . 0 3 9 8}^{\star *}$ & 0.5791 \\
\hline
\end{tabular}

${ }^{*} p=0.0401$ Student Independent $t$-test; ${ }^{* *}$ One-Way ANOVA test

Table 5 - Comparison of IL-17A Flow Cytometry analysis in the Infection Control and the Infection Experimental group, in mice, IEC, Brazil, 2020.

\begin{tabular}{ccc}
\hline & \multicolumn{1}{c}{ IL 17a $^{*}$} \\
\hline $\begin{array}{c}\text { Time } \\
\text { (days) }\end{array}$ & $\begin{array}{c}\text { Control group } \\
\text { Mean } \pm \text { SD }\end{array}$ & $\begin{array}{c}\text { Tetrahydrobiopterin } \\
\text { group } \\
\text { Mean } \pm \text { SD }\end{array}$ \\
\hline 3 & $7.5367 \pm 1.06$ & $8.5067 \pm 1.33$ \\
9 & $7.4200 \pm 1.97$ & $6.9133 \pm 0.51$ \\
13 & $7.0533 \pm 0.78$ & $6.5600 \pm 0.41$ \\
\hline Result & -0.4834 & -1.9467 \\
p-value & 0.8824 & 0.1165 \\
\hline
\end{tabular}

${ }^{*} p=0.0146$ Student Independent t-test; ${ }^{* *}$ One-Way ANOVA test

Table 6 presents the results of the Anti-iNOS during the days in which the animals were euthanized, and there was no difference in the quantification of antibody markers between the groups $(\mathrm{p}=0.0066)$.

\section{DISCUSSION}

Human rabies is considered to be a controlled disease 
Table 6 - Comparison of INOS immunohistochemistry analysis in the Infection Control and the Infection experimental group, IEC, Brazil, 2020.

\begin{tabular}{cccc}
\hline \multicolumn{4}{c}{ Anti-iNOS } \\
\hline $\begin{array}{c}\text { Time } \\
\text { (days) }\end{array}$ & $\begin{array}{c}\text { Tetrahydrobiopterin } \\
\text { group }\end{array}$ & Control group & p-value \\
\cline { 2 - 4 } & Mean \pm SD & Mean \pm SD \\
\hline 3 & $0.019792 \pm 0.009$ & $0.06563 \pm 0.023$ & $\mathbf{0 . 0 1 6 4}{ }^{\star}$ \\
5 & $0.120834 \pm 0.044$ & $0.10208 \pm 0.030$ & 0.2875 \\
7 & $0.234375 \pm 0.075$ & $0.24306 \pm 0.081$ & 0.4491 \\
9 & $0.180729 \pm 0.092$ & $0.35052 \pm 0.128$ & 0.0673 \\
11 & $0.280209 \pm 0.011$ & $0.35260 \pm 0.017$ & 0.2875 \\
13 & $0.272917 \pm 0.019$ & $0.29948 \pm 0.014$ & 0.4276 \\
\hline Result & +0.253125 & +0.23385 & \\
p-value & $\mathbf{0 . 0 0 6 6 * *}$ & $\mathbf{0 . 0 2 7 3}$ & \\
\hline
\end{tabular}

*Student Independent t-test; **One-Way ANOVA test

due to the widespread use of vaccines and immunoglobulins, but lethal cases after the bite of contaminated non-human mammals still occur, mainly in developing countries. There are an estimated 59,000 cases of deaths annually in more than 150 countries, most of which occur in Africa and Asia, so the establishment of a treatment for the disease already installed is necessary and one of the drugs indicated in the Milwaukee Protocol currently in vigor, is sapropterin ${ }^{3,4,6,7}$.

The main indication for tetrahydrobiopterin (BH4), and its pharmacological form sapropterin, is for the severe form of phenylketanuria, an autosomal recessive genetic disease that generates errors in the enzyme phenylalanine hydroxylase, an essential cofactor for dopamine, noradrenaline and serotonin, leading to clinically with delayed psychomotor development, microcephaly, tremors and limb uncoordination ${ }^{8}$.

In human rabies, one of the therapeutic advantages of the use of sapropterin is the low levels of $\mathrm{BH} 4 \mathrm{~s}$ in the CSF of patients treated with the disease already installed, and in association with other drugs, the possible beneficial effects on the pathophysiology of the disease, possibly changing the outcome of the disease, that in most cases islethal ${ }^{8,12}$.

The inflammatory process generated by the virus is the main responsible for the lethality of the disease, as stated by Hooper ${ }^{13}$. The mechanism of response to depletion of most viruses initially passes through cytotoxicity and apoptosis of infected cells that is later used by the immune system via a specific mechanism of neutralization carried out by antibodies against viral surface proteins - participating in the adaptive immunity ${ }^{13,14}$.

The activation and stimulation of cytotoxic cells, as well as the stimulation of apoptosis, instigated by several types of $\mathrm{T}$ lymphocytes, are extremely harmful elements in the nervous tissue, since it has little margin for plasticity and regeneration when compared to other tissues. In addition to this nerve cell destruction factor, there is also a tissue edema that generates dysfunction and dysautonomy, very common in patients infected with the rabies virus ${ }^{15-17}$.

These two mechanisms are closely related to the activity of Interleukin 6 (IL-6), which is responsible for increasing the exposure capacity of adhesion molecules on the wall of brain vessels, facilitating the migration of white cells to the CNS, in addition to promoting the entry of liquid content, rich in antibodies and other inflammatory mediators, thus initiating an exponential cycle of innate inflammatory response, which stimulates activities that, in controlled doses, are capable of generating healing in mice with installed rabies. However, in cases with high IL-6 expression, neuronal loss begins, with irreversible and lethal sequelae $e^{18-20}$.

In rabies strains, with high potential for IL6 expression, a high neuronal injury power is observed, due to the high expression of type I histocompatibility molecules with greater activity of CD4 cells. This element can occur through IFN-gamma (interferon gamma) mediation, which is also a stimulator of adhesion molecules on the endothelial wall of CNS cells, in addition to being a ripener of macrophages ${ }^{21,22}$.

In the present study, it is possible to observe that there is a sign of decrease in the concentration of IL- 6 in the group submitted to the studied drug, IL-6 $(\mathrm{p}=0.21)$ and INF-gamma ( $\mathrm{p}=0.38)$, are important actors in the control of the inflammatory response at the CNS level in response to rabies infection, since, with a greater control of the entry of cytotoxic cells, the innate response of the immune system will suffer less damage, being an appropriate time for the adaptive immunity to respond in an increasing way, without causing serious sequelae or death, which could help explaining the success of cases in humans submitted to the Milwaukee protocol. The decrease in viral concentrations was found in the experimental group, which demonstrates a greater viral clearance capacity related to the use of the drug, at least in this murine model ${ }^{23-25}$.

As stated by Luo et al. ${ }^{18}$, the more immunogenic the viral strain, the greater the ability of the antibody to generate an immune response, but also generating more neuronal damage through the innate response. It is worth noting that in the case of a negative regulation of the immune response, mainly of IL-6, INF- gamma and TNF, there will be a better systemic response, so that viral strains with overexposure to IL-6 can generate more damage 18,26,27 $^{\text {. }}$

Along with the two immunological mediators already discussed, IL17, which is produced by TCD4 cells and is closely related to cell recruitment, decreased in the experimental infection group. Interestingly, the 
experimental group ( $\mathrm{p}=0.014)$, showed less IL-2 depletion, which is extremely important mainly for the maturation of $\mathrm{T}$ and $\mathrm{B}$ lymphocytes, being responsible for the innate and adaptive immune response, respectively. The total non-depletion of IL2 is necessary for activities within the micro environment of the CNS, as it will assist in the maturation of white cells for the immediate innate response and controlling the viral dispersion within the $\mathrm{CNS}^{28-33}$.

As for the inducible NOS (iNOS), it is an element of the nitric oxide synthase (NOS) family, which acts as an inflammatory mediator, mainly for microglia and macrophages. It is an important mediator of the inflammatory process in infectious diseases, in the present study, changes in this marker were not observed in either the experimental group or in the control group ( $\mathrm{p}=0.006$ ). It can be inferred that the drug does not interfere with the activity of cells that use iNOS as an immune mediator in the CNS, which was expected, since $\mathrm{BH} 4$ is not an essential component in the synthesis of NOS $^{34,35}$.

Even with criticisms of the Milwaukee protocol, it is currently applied to patients with an installed viral infection, but the role of each drug is still speculated, requiring studies in experimental and clinical models, even if experimental models are difficult to manage, due to the power of viral lethality and the need for a high biosafety laboratory structure.

\section{CONCLUSION}

The present study suggests that the use of sapropterin in mice infected with the wild rabies virus has a significant impact on the permeability and integrity of the cephalic blood-brain barrier, mainly through mechanisms mediated by IL-6. However, further studies using tools such as mRNA of inflammatory mediators are needed to verify the integrity of the blood-brain barrierto deepen and elucidate the mechanism indicated by this research.

Based on the data found, it is possible to suggest that the influence of tetrahydrobiopterin on the CNS inflammatory process of infected mice was affected to regulate the inflammatory process, thus generating a possible decrease in cytotoxic cells, which migrated to the CNS due to the fragility of the $r$ hematoencephalic barrier and preserving neural tissue. More studies regarding the interaction of drugs, viral infection and the immune system, are needed to elucidate the positive impacts obtained with the use of different drugs of the Milwaukee protocol in humans.

\section{ACKNOWLEDGMENTS}

We appreciate the support of the Evandro Chagas Institute and its Postgraduate Program in Virology. We are grateful for the support of Prof. Luiz Carlos Santana da Silva, from the Laboratory of Inborn Errors of Metabolism at the Federal University of Para, Brazil, for having made contact between researchers and the laboratories that made the drugs used in this research.

\section{CONFLICT OF INTERESTS}

The authors declare no conflict of interests.

\section{ETHICAL STATEMENT}

The experiment was conducted at the laboratory of the Evandro Chagas Institute with the approval of the Ethics Committee on Animal Use (CEUA) of the Evandro Chagas Institute (IEC), under the $\mathrm{N}^{\circ} 37 \backslash 2017$, approved on September 13, 2017.

\section{FUNDING}

There was no funding for this research project.

\section{REFERENCES}

1. Jackson AC. Therapy of human rabies. In: Jackson AC, editor. Rabies: scientific basis of the disease and its management. $3^{\text {rd }}$ ed. Amstredam: Academic Press; 2013. p.575-89.

2. Hunter M, Johnson N, Hedderwick S, McCaughey C, Lowry $\mathrm{K}$, McConville $\mathrm{J}$, et al. Immunovirological correlates in human rabies treated with therapeutic coma. J. Med Virol. 2010;82:1255-65.

3. Lima FG, Gagliani LH. Raiva: aspectos epidemiológicos, controle e diagnóstico laboratorial. Rev UNILUS Ens Pesqui. 2014;11:45-62.

4. Brock Fenton M, Streicker DG, Racey PA, Tuttle MD, Medellin RA, Daley M, et al. Knowledge gaps about rabies transmission from vampire bats to humans. Nat Ecol Evol. 2020;4:517-8.

5. Aramburo A, Willoughby RE, Bollen AW, Glaser CA, Hsieh CJ, Davis SL, et al. Failure of the Milwaukee protocol in a child with rabies. Clin Infect Dis. 2011;53:572-4.

6. van Thiel PP, de Bie RM, Eftimov F, Tepaske R, Zaaijer HL, van Doornum GJ, et al. Fatal human rabies due to Duvenhage virus from a bat in Kenya: failure of treatment with comainduction, ketamine, and antiviral drugs. PLoS Negl Trop Dis. 2009;3:e428.

7. Willoughby RE Jr. Rabies: rare human infection: common questions. Infect Dis Clin North Am. 2015;29:637-50.

8. Willoughby RE, Opladen T, Maier T, Rhead W, Schmiedel S, Hoyer J, et al. Tetrahydrobiopterin deficiency in human rabies. J Inherit Metab Dis. 2009;32:65-72.

9. O’Sullivan A, Willoughby RE, Mishchuk D, Alcarraz B, Cabezas- 
Sanchez C, Condori RE, et al. Metabolomics of cerebrospinal fluid from humans treated for rabies. J Proteome Res. 2013;12:481-90.

10. Aguayo M. Interpretación del método de Reed y Muench para verificar la potencia de sueros y vacunas. Salud Publica Mex. 1960;2:357-9.

11. Oberhuber R, Ritschl P, Fabritius C, Nguyen AV, Hermann M, Obrist $\mathrm{P}$, et al. Treatment with tetrahydrobiopterin overcomes brain death-associated injury in a murine model of pancreas transplantation. Am J Transplant. 2015;15:2865-76.

12. Willoughby RE, Roy-Burman A, Martin KW, Christensen JC, Westenkirschner DF, Fleck JD, et al. Generalised cranial artery spasm in human rabies. Dev Biol (Basel). 2008;131:367-75.

13. Hooper DC. The role of immune responses in the pathogenesis of rabies. J Neurovirol. 2005;11:88-92.

14. Nazé F, Suin V, Lamoral S, Francart A, Brochier B, Roels S, et al. Infectivity of rabies virus-exposed macrophages. Microbes Infect. 2013;15:115-25.

15. Palus M, Formanová P, Salát J, Žampachová E, Elsterová J, Růžek D. Analysis of serum levels of cytokines, chemokines, growth factors, and monoamine neurotransmitters in patients with tick-borne encephalitis: identification of novel inflammatory markers with implications for pathogenesis. J Med Virol. 2015;87:885-92.

16. Formanova PP, Palus M, Salat J, Hönig V, Stefanik M, Svoboda $\mathrm{P}$, et al. Changes in cytokine and chemokine profiles in mouse serum and brain, and in human neural cells, upon tick-borne encephalitis virus infection. J Neuroinflammation. 2019;16:205.

17. Hooper DC, Kean RB, Scott GS, Spitsin SV, Mikheeva T, Morimoto K, et al. The central nervous system inflammatory response to neurotropic virus infection is peroxynitrite dependent. J Immunol. 2001;167:3470-7.

18. Luo J, Zhang B, Wu Y, Tian Q, Mo M, Long T, et al. Recombinant rabies virus expressing interleukin- 6 enhances the immune response in mouse brain. Arch Virol. 2018;163:1889-95.

19. Fabis MJ, Phares TW, Kean RB, Koprowski H, Hooper DC. Blood-brain barrier changes and cell invasion differ between therapeutic immune clearance of neurotrophic virus and CNS autoimmunity. Proc Natl Acad Sci U S A. 2008;105:15511-6.

20. Phares TW, Kean RB, Mikheeva T, Hooper DC. Regional differences in blood-brain barrier permeability changes and inflammation in the apathogenic clearance of virus from the central nervous system. J Immunol. 2006;176:7666-75.

21. Erndt-Marino J, Yeisley DJ, Chen H, Levin M, Kaplan DL, Hahn MS. Interferon-gamma stimulated murine macrophages in vitro: impact of ionic composition and osmolarity and therapeutic implications. Bioelectricity. 2020;2:48-58.

22. Abdulazeez M, Kia GS, Abarshi MM, Muhammad A, Ojedapo CE, Atawodi J C, et al. Induction of rabies virus infection in mice brain may up and down regulate type II interferon gamma via epigenetic modifications. Metab Brain Dis. 2020;35:819-27.

23. Manjunatha V, Singh KP, Saminathan M, Singh R, Shivasharanappa $\mathrm{N}$, Umeshappa CS, et al. Inhibition of MEK-ERK1/2-MAP kinase signalling pathway reduces rabies virus induced pathologies in mouse model. Microb Pathog. 2017;112:38-49.

24. Appelgren D, Enocsson H, Skogman BH, Nordberg M, Perander L, Nyman D, et al. Neutrophil extracellular traps (NETs) in the cerebrospinal fluid samples from children and adults with central nervous system infections. Cells. 2019;9:43.

25. Mangale V, Syage AR, Ekiz HA, Skinner DD, Cheng Y, Stone $\mathrm{CL}$, et al. Microglia influence host defense, disease, and repair following murine coronavirus infection of the central nervous system. Glia. 2020;68:2345-60.

26. Garcia SA, Lebrun A, Kean RB, Hooper DC. Clearance of attenuated rabies virus from brain tissues is required for long-term protection against CNS challenge with a pathogenic variant. J Neurovirol. 2018;24:606-15.

27. Marosi A, Dufkova L, Forró B, Felde O, Erdélyi K, Širmarová J, et al. Combination therapy of rabies-infected mice with inhibitors of pro-inflammatory host response, antiviral compounds and human rabies immunoglobulin. Vaccine. 2019;37:4724-35.

28. Chawla AS, Khalsa JK, Dhar A, Gupta S, Umar D, Arimbasseri $\mathrm{GA}$, et al. A role for cell-autocrine interleukin-2 in regulatory T-cell homeostasis. Immunology. 2020;160:295-309.

29. Kolbinger F, Huppertz C, Mir A, Di Padova F. IL-17A and multiple sclerosis: signaling pathways, producing cells and target cells in the central nervous system. Curr Drug Targets. 2016;17:1882-93.

30. Phares TW, Kean RB, Mikheeva T, Hooper DC. Regional differences in blood-brain barrier permeability changes and inflammation in the apathogenic clearance of virus from the central nervous system. J Immunol. 2006;176:7666-75.

31. Kim HM, Shin HY, Jeong HJ, An HJ, Kim NS, Chae HJ, et al. Reduced IL-2 but elevated IL-4, IL-6, and IgE serum levels in patients with cerebral infarction during the acute stage. J Mol Neurosci. 2000;14:191-6.

32. Aram J, Frakich N, Morandi E, Alrouji M, Samaraweera A, Onion D, et al. Increased IL-2 and reduced TGF- $\beta$ upon T-cell stimulation are associated with GM-CSF upregulation in multiple immune cell types in multiple sclerosis. Biomedicines. 2020;8:226.

33. Rua R, Pujol N. IL-17: good fear no tears. Nat Immunol. 2020;21:1315-6.

34. Martina BE, Smreczak M, Orlowska A, Marzec A, Trebas P, Roose JM, et al. Combination drug treatment prolongs survival of experimentally infected mice with silver-haired bat rabies virus. Vaccine. 2019;37:4736-42.

35. Bogdan C. Nitric oxide synthase in innate and adaptive immunity: an update. Trends Immunol. 2015;36:161-78. 